\title{
KELOMPOK TANI DAN IBU PKK DESA WAJOKHILIR MELALUI PELATIHAN DIVERSIFIKASI PRODUK OLAHAN BERBASIS KELAPA DAN PISANG
}

\author{
Group of Agriculture and Mothers of PKK in the Wajokhilir Village through Training \\ Diversifications of Coconut Based Products and Banana
}

\section{Tashadi Tarmidji ${ }^{1)}$ dan Muhammad Ali ${ }^{1)}$}

${ }^{1}$ Politeknik Negeri Pontianak, Jurusan Akuntansi dan Teknologi Pengolahan Hasil Perkebunan, Jalan Jenderal Ahmad Yani Pontianak, Kalimantan Barat 78124

email : bunk_t2@yahoo.com

\begin{abstract}
Wajok Hilir Village, Siantan District, Mempawah Regency is a very potential area in its agricultural products in the form of coconut and Kepok banana and still very limited its utilization to be food product. Through this PPM IbM activity, the goals will be: to provide information on knowledge and skill of IPTEKS diversification of coconut and banana to farmer group "Bina Usaha" and Ibu PKK as partner group. Methods of Activities to be implemented are technology transfer and entrepreneurship in the form of training and technical guidance to partners in production, Entrepreneurship Training, Bookkeeping training and marketing strategy. PKM activities can be accepted by community partners, this can be shown by the enthusiasm of the trainees, besides the training participants have the ability to make their own processed coconut and banana products with attractive packaging and open a small business to increase income family income.
\end{abstract}

Keywords: Coconut, banana, entrepreneurship, PKK group and farmer group "Bina Usaha"

\begin{abstract}
ABSTRAK
Desa Wajok Hilir Kecamatan Siantan Kabupaten Mempawah merupakan wilayah yang sangat potensial pada hasil pertaniannya berupa tanaman kelapa dan pisang jenis Kepok dan masih sangat terbatas pemanfaatannya menjadi produk pangan. Melalui Kegiatan PPM IbM ini tujuanyang akan dilakukan adalah : memberikan informasi pengetahuan dan ketrampilan IPTEKS diversifikasi kelapa dan pisang pada kelompok Tani "Bina Usaha" dan Ibu PKK sebagai kelompok mitra . Metode Kegiatan yang akan dilaksanakan adalah Transfer Teknologi Ipteks dan Kewirausahaan (Entrepreneurship)berupa pelatihan dan bimbingan teknis terhadap mitra dalam berproduksi, Pelatihan Kewirausahaan, Pelatihan pembukuan dan strategi pemasaran .Kegiatan PKM ini dapat diterima oleh masyarkat mitra, hal ini dapat ditunjukkan dengan antusiasnya peserta pelatihan, selain itu peserta pelatihan memiliki kemampuan untuk membuat sendiri aneka olahan produk kelapa dan pisang dengan kemasan yang menarik dan membuka usaha kecil untuk menambah income pendapatan keluarga
\end{abstract}

Kata Kunci : Kelapa,Pisang, Entrepreneurship, kelompok PKK dan Kelompok Tani "Bina Usaha"

\section{PENDAHULUAN}

Desa Wajok Hilir merupakan salah satu desa yang berada di Kecamatan Siantan Kabupaten Mempawah Kalimantan Barat dengan luas wilayah23.350 Ha dan penduduk berjumlah 10.605 jiwa terdiri dari jumlah penduduk laki-laki 5.364 jiwa dan perempuan 5.241 jiwa. Secara geografis, batas wilayah desa Wajok Hilir bagian 
utara berbatasan dengan Desa Peniti Dalam I Kecamatan Segedong, bagian selatan berbatasan dengan Sungai Kapuas Kecamatan Kakap, bagian barat berbatasan dengan desa Jungkat Kecamatan Siantan dan bagian timur berbatasan dengan desa Wajok Hulu Kecamatan Siantan.

Mata pencaharian penduduk sebagian besar bekerja sebagaipetani kelapa dan pisang. Kedua komoditi tersebut menjadi produk unggulan desa Wajok Hilir dan sampai saat ini desa Wajok Hilir merupakan salah satu daerah penghasil utama kelapa dan pisang di kecamatan Siantan. Kelompok tani yang banyak mengembangkan tanaman kelapa di wilayah Wajok Hilir yang dipimpin oleh Bapak M. Nasir H. Ali berada pada Dusun Parit Sy.Abubakar. Berdasarkan informasi yang diperoleh bahwa Kelompok tani yang terdapat di Wajok Hilir berjumlah 16 kelompok, dimana 10 kelompok diantaranya merupakan petani kelapa dan pisang. Pada umumnya kelapa dipasarkan dalam bentuk segar dan dijual kepada pedagang pengumpul dengan harga kelapa Rp. 2000/buah, dan harga pisang kepok Rp. 1500/kg. Selain itu sebagian besar petani kelapa di desa tersebut mengolah kelapa menjadi kopra kemudian menjualnya kepada pedagang pengumpul dan dikirimkan ke pabrik minyak kelapa untuk diolah minyak.

Sedangkan pisang hanya diolah secara konvensional serta dikonsumsi oleh masyarakat itu sendiri dalam bentuk pisang di rebus/goreng/keripik, sehingga nilai ekonomisnya masih relatif rendah. Banyaknya kelapa dan pisang didesa Wajok Hilir memberi potensi dan peluang usaha bagi masyarakat setempat untuk melakukan diversifikasi kelapa dan pisang yaitu dari bagian daging buah sampai pada bagian limbahnya.

Pengolahan kelapa menjadi kopra di desa Wajok Hilir menghasilkan limbah berupa air kelapa yang sangat potensial untuk dimanfaat menjadi produk yang bernilai ekonomis tinggi. Limbah tersebut selama ini masih belum dimanfaatkan secara maksimal oleh masyarakat Wajok Hilir. Air kelapa merupakan hasil samping dari produksi kopra atau kelapa parut kering. Limbah air kelapa seringkali menimbulkan masalah bila terdapat dalam jumlah yang cukup besar. Limbah yang terfermentasi, akan menyebabkan polusi bau busuk yang mengganggu lingkungan (Yuliani, 2011). Komponen yang terpenting yang terdapat di dalam air kelapa adalah karbohidrat (gula). Air kelapa dari buah yang sudah tua mengandung sukrosa, vitamin $\mathrm{C}$ dan mineral, terutama kalium (Pembayun, 2002). Air kelapa bisa dibuat makanan yang disebut nata de coco, kecap air kelapa dan sirup (Palungkun, 1993).

Berdasarkan pertimbangan diatas menunjukkan bahwa air kelapa sangat potensi untuk diolah dan memiliki prospek pasar yang sangat potensial sehingga pemanfaatan limbah air kelapa merupakanupaya pemanfaatan limbah menjadi produk yang memiliki nilai tambah (Sukamto, 2001). Sedangkan Pengolahan pisang pada umumnya diolah pada bagian buahnya saja menjadi keripik pisang, kolak, pisang goreng dan pisang rebus (Rukmana, 1991). Padahal semua bagian tanaman pisang dapat diolah menjadi produk pangan yang kaya akan karbohidrat, vitamin, mineral dan serat yang tinggi yaitu dari bagian kulit pisang, batang, bonggol dan jantung pisang (Munadjin, 1983). Salah satu bentuk diversifikasi produk pisang yaitu, selai pisang (Fachruddin, 2008).

Berkaitan dengan tingkat pendidikan masyarakat desa Wajok Hilir yang mayoritas tamatan SD maka pada umumnya masyarakat desa akan lebih mudah mengerti dan yakin terhadap informasi baru apabila telah mengerti, memahami, mengalami sendiri hasilnya sehingga mampu untuk mempertimbangkan dan menilai suatu kegiatan. Disamping itu faktor transportasi yang masih terbatas ditambah akses jalan yang mengalami kerusakan sehingga mengakibatkan terlambatnya arus informasi IPTEK sampai ketingkat petani dan minimnya pengetahuan masyarakat petani tentang budidaya, penanganan dan pengolahan hasil pertanian termasuk 
penanganan kelapa dan pisang. Padahal penanganan hasil panen dirasakan sangat diperlukan terutama pada saat terjadi panen raya didaerah sentra kelapa dan pisang yang seringkali menyebabkan jatuhnya harga kelapa dan pisang.

Sasaran Kegiatan pengabdian pada masyarakat (PKM) ini ditujukan pada kelompok tani "Bina Usaha" dan kelompok ibu PKK karena Kedua mitra tersebut dikategorikan belum produktif dengan alasan berikut:

1. Kedua mitra tersebut mayoritas sebagai istri dan anak petani pisang dan kelapa dengan produksi yang melimpah

2. Selama ini kedua mitra tersebut telah mekakukan produksi (kopra dan keripik pisang) dengan keterbatasan pengetahuan dan ketrampilan IPTEK, modal dan jangkauan pemasaran

3. Kedua mitra memiliki semangat untuk berwirausaha dengan mengolah potensi lokal yang ada

\section{BAHAN DAN METODE}

\section{Bahan}

Bahan yang digunakan untuk olahan kelapa dan pisang meliputi : kelapa tua, kelapa muda, pisang, starter, sitrat, gula pasir, gula halus, telur mentega, tepung pisang, tepung terigu, maizena, coklat susu bubuk, susu kental manis, bumbu aneka rasa, vanili, baking powder, masako, minyak goreng, meseseres dan tepung panir.

\section{Alat}

Alat yang digunakan untuk olahan kelapa dan pisang meliputi : blender, mixer,seperangkat kompor gas, oven, , loyang aluminium, parutan, nampan, baskom, pisau, dandang, kuali, panic, sendok penggoreng dan peniris, ayakan, cetakan kue.

\section{Metode Pelaksanaan}

Adapun metode Pelaksanaaan pengabdian pada masyarakat sebagai berikut:
1. Memberikan penyuluhan berupa penjelasan pengetahuan kepada masyarakat dengan materi aneka olahankelapa dan pisang, teknik pengemasan, pembukuan, strategi Pemasaran, kewirausahaan dengan menyiapkan brosur dan modul pelatihan.

2. Melakukan pelatihanpembuatan olahan produk kelapa (kelapa parut kering, coco cake, selai, nata de coco, sirup dan kecap air kelapa dan pisang (tepung pisang, cookies, nugget jantung pisang, jarringjaring pisang aneka rasa, keripik kulit dan bonggol pisang) dengan membentuk kelompok kecil yang terdiri dari 4 atau 5 orang perkelompok. Masing-masing kelompok didampingi oleh tim pelaksana PKM.

\section{HASIL DAN PEMBAHASAN}

Upaya pengembangan wawasan pengetahuan dan keterampilan masyarakat mitra desa wajok Hilir maka program pengabdian masyarakat ini dilakukan dalam bentuk transfer IPTEK yang dilakukan berupa sosialisasi, pelatihan, kepada kelompok tani dan Ibu PKK yang akan mengolah hasil kelapa dan pisang yang semula hanya terbatas pada penjualan dalam bentuk segarnya, dikembangkan melalui pembekalan wawasan pengetahuan dan keterampilan praktik olahan produk, kewirausahaan,teknik pengemasan, penyusunan pembukuan sederhana dan pemasaran sehingga menjadi beraneka ragam jenis produk yang sifatnya inovatif untuk membuka peluang usaha bagi masyarakat mitra sebagai upaya meningkatkan pendapatan mitra sehari-hari.

Dalam menjalankan kegiatan ini tentu saja tidak terlepas dari kerjasama antara mitra dengan pelaksana kegiatan Program Pengabdian Kepada Masyarakat. Partisipasi mitra sangat diharapkan untuk terlaksananya kegiatan ini. Mitra dalam kegiatan ini sebagai peserta pelatihan juga sebagai masyarakat yang akan menerima informasi pelatihan tentang pengolahan kelapa dan pisang sehingga mitra mempunyai 
kemampuan dan keahlian untuk mengolah hasil-hasil pertanian. Dalam kegiatan ini diharapkan Kelompok Tani dan ibu PKK dapat berpartisipasi secara aktif agar program dapat berjalan lancar dan sukses. Partisipasi yang mitra berikan meliputi :

a. Menyiapkan lokasi dan tempat bagi pelaksanaan kegiatan PKM

b. Memfasilitasi penyediaan bahan baku kelapa dan pisang untuk kegiatan pelatihan.

Untuk mengukur tingkat keberhasilan kegiatan yang telah dilakukan, maka akan dilakukan evaluasi. Kegiatan evaluasi ini akan melibatkan tim UPPM POLNEP. Kriteria dan indikator pencapaian tujuan dan tolak ukur yang digunakan untuk menjastifikasi tingkat keberhasilan kegiatan
Setelah diberikan sosialisasi oleh tim pelaksana PKM, dengan harapan Ibu PKK dan kelompok Tani di Desa Wajok Hilir dapat memahami dengan jelas materi sosialisasi dan pelatihan mengenai teknik olahan produk dalam hal pengolahan kelapa dan pisang, pelatihan pembukuan sederhana dan teknik pemasaran. Berdasarkan evaluasi yang dilakukan, ditemukan bahwa Ibu PKK dan kelompok tani di Desa Wajok Hilir yang mengikuti pelaksanaan program memiliki pengetahuan dan keterampilan pengolahan produk, dan keterampilan penyusunan pembukuan. Hasil penilaian peserta/mitra sebelum dan setelah kegiatan PKM dan penilaian terhadap produk olahan pisang dan kelapa diperoleh hasil sebagai berikut:

Tabel 1. Hasil penilaian peserta sebelum dan setelah kegiatan PPM

\begin{tabular}{|c|c|c|c|}
\hline Kegiatan & $\begin{array}{l}\text { Sebelum } \\
\text { kegiatan }\end{array}$ & $\begin{array}{l}\text { Setelah } \\
\text { kegiatan }\end{array}$ & Luaran \\
\hline $\begin{array}{l}\text { Aktivitas dan partisipasi } \\
\text { mitra dalam mengikuti } \\
\text { kegiatan PKM }\end{array}$ & $\begin{array}{c}12 \text { orang } \\
48 \%\end{array}$ & $\begin{array}{c}25 \text { orang } \\
100 \%\end{array}$ & $\begin{array}{l}\text { Mitra sangat antusias dan termotivasi } \\
\text { dalam menerima inovasi baru }\end{array}$ \\
\hline $\begin{array}{l}\text { Penyampaian materi } \\
\text { olahan kelapa dan } \\
\text { pisang }\end{array}$ & $\begin{array}{l}5 \text { orang } \\
20 \%\end{array}$ & $\begin{array}{c}25 \text { orang } \\
100 \%\end{array}$ & $\begin{array}{l}\text { Peningkatan pengetahuan dan wawasan } \\
\text { IPTEK mitra tentang Olahan Kelapa } \\
\text { dan pisang }\end{array}$ \\
\hline $\begin{array}{l}\text { Pelatihan Olahan produk } \\
\text { kelapa dan pisang }\end{array}$ & $\begin{array}{l}7 \text { orang } \\
28 \%\end{array}$ & $\begin{array}{c}23 \text { orang } \\
92 \%\end{array}$ & $\begin{array}{lcr}\text { Peningkatan } & \text { kemampuan } & \text { dan } \\
\text { ketrampilan } & \text { mitra } & \text { dalam } \\
\text { mempraktekkan olahan produk } & \text { sesuai } \\
\text { dengan spesifikasi produk } & \end{array}$ \\
\hline $\begin{array}{l}\text { Penggunaan alat dan } \\
\text { peralatan olahan produk }\end{array}$ & $\begin{array}{c}8 \text { orang } \\
32 \%\end{array}$ & $\begin{array}{c}25 \text { orang } \\
100 \%\end{array}$ & $\begin{array}{l}\text { Mitra trampil dalam menggunakan } \\
\text { peralatan pengolahan }\end{array}$ \\
\hline Pelatihan pembukuan & $\begin{array}{c}2 \text { orang } \\
8 \%\end{array}$ & $\begin{array}{c}23 \text { orang } \\
92 \%\end{array}$ & $\begin{array}{l}\text { Mitra sudah memahami Teknik } \\
\text { pembukuan sederhana }\end{array}$ \\
\hline Pelatihan kewirausahaan & $\begin{array}{c}3 \text { orang } \\
12 \%\end{array}$ & $\begin{array}{c}23 \text { orang } \\
92 \%\end{array}$ & $\begin{array}{l}\text { Peningkatan keinginan dan ketertarikan } \\
\text { mitra untuk menjadi wirausaha }\end{array}$ \\
\hline
\end{tabular}


Tabel 2. Hasil Penilaian Terhadap Produk olahan pisang dan Kelapa

\begin{tabular}{|c|c|c|c|c|}
\hline Produk & Penampilan & $\begin{array}{c}\text { Nilai } \\
\text { jual }\end{array}$ & $\begin{array}{c}\text { Sumber } \\
\text { bahan } \\
\text { baku }\end{array}$ & $\begin{array}{c}\text { Proses } \\
\text { pembuatannya }\end{array}$ \\
\hline $\begin{array}{l}\text { Kelapa parut kering, coco cake, } \\
\text { selai, nata de coco, sirup dan } \\
\text { kecap air kelapa }\end{array}$ & Menarik100\% & $\begin{array}{l}\text { Memiliki } \\
\text { nilai jual } \\
100 \%\end{array}$ & $\begin{array}{l}\text { Mudah } \\
\text { didapat } \\
100 \%\end{array}$ & $\begin{array}{l}\text { Mudah } \\
\text { dilaksanakan } \\
98 \%\end{array}$ \\
\hline $\begin{array}{l}\text { Tepung pisang, cookies, jaring- } \\
\text { jaring pisang aneka rasa } \\
\text { sedangkan limbahnya berupa } \\
\text { jantung pisang diolah menjadi } \\
\text { nugget, keripik kulit dan } \\
\text { bonggol pisang }\end{array}$ & $\begin{array}{l}\text { Menarik } \\
100 \%\end{array}$ & $\begin{array}{l}\text { Memiliki } \\
\text { nilai jual } \\
100 \%\end{array}$ & $\begin{array}{l}\text { Mudah } \\
\text { didapat } \\
100 \%\end{array}$ & $\begin{array}{l}\text { Mudah } \\
\text { dilaksanakan } \\
95 \%\end{array}$ \\
\hline
\end{tabular}

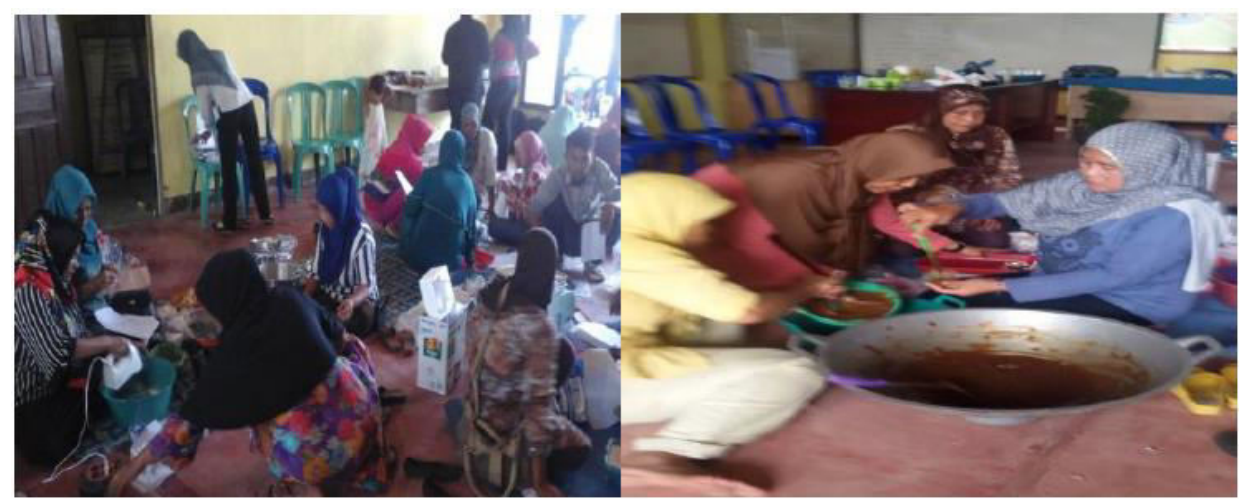

Gambar 1. Aktivitas mitra dalam pelatihan pembuatan produk

Berdasarkan hasil evaluasi dan indikator keberhasilan : Kegiatan PKM ini mendapatkan respon positif dari masyarakat. Hal ini terlihat dari kehadiran masyarakat dan keaktifan masyarakat dalam mendengarkan penjelasan tentang cara pengolahan diversifikasi pisang dan kelapa menjadi makanan yang enak, bergizi dan bernilai ekonomis. Selain itu pada sesi tanya jawab peserta mitra sangat bersemangat dan sangat antusias mengetahui teknik pengolahan, teknik pengemasan (Susanto dan Sucipto, 1994), teknik pembukuan, teknik pemasaran dan kewirausahaan. Ini menunjukkan Adanya Kemauan dan semangat Masyaakat mitra di desa Wajok Hilir dalam menerima inovasi baru. Peningkatan wawasan dan ketranpilan mitra dalam membuat aneka olahan kelapa dan pisang mendorong sebagian Besar Masyarakat Mitra tertarik untuk membuat sendiri karena proses pengolahannya sederhana dan berusaha membuka usaha kecil setelah adanya pelatihan ini. Adapun aktifitas mitra dalam pelaksanaan PKM dapat dilihat pada Gambar 1.

\section{KESIMPULAN}

Kesimpulan yang dapat diperoleh dari pelaksanaan program pengabdian kepadamasyarakat "Kelompok Tani dan kelompok PKK Desa Wajok Hilir, Kecamatan Siantan, Kabupaten Mempawah, adalah:

1. Tingkat partisipasi yang tinggi dari mitra program pengabdian kepada masyarakatmemberikan dampak positif 
bagi pelaksanaan program, terlihat mitra termotivasi untuk maju dan mandiri, mulai dari pelatihan danpendampingan olahan berbahan baku kelapa dan pisang menghasilkan produk sesuai dengan spesifikasi yang diinginkan,cara pengemasan yang baik dan menarik serta sudah memahami teknik pembukuan sederhana

2. Pelaksanaan program mampu memberi semangat dan motivasi mitra untuk membuka peluang usaha kecil dari potensi lokal sebagai upaya meningkatkan perekonomian keluarga.

\section{DAFTAR PUSTAKA}

Fachruddin L. 2008. Membuat aneka selai. Kanisius. Yogyakarta.
Munadjim. 1983. Teknologi pengolahan pisang. Gramedia. Jakarta.

Palungkun, R. 1993. Aneka produk olahan kelapa. Penebar Swadaya. Jakarta.

Rukmana, R. 1999. Usaha tani pisang. Kanisius. Yogyakarta

Pembayun. 2002. Teknologi nata de coco. Penerbit Kanisius. Yogyakarta..

Susanto, T dan Sucipto, N. 1994. Teknologi pengemasan bahan makanan. CV. Family. Blitar

Sukamto. 2001. Upaya meningkatkan produksi kelapa. Penebar Swadaya. Jakarta.

Yuliani, H.R. 2011. Karakterisasi selai tempurung kelapa muda. Prosiding Seminar Nasional Teknik Kimia "Kejuangan". Yogyakarta. 